\title{
Thoughts on Technological Diversity and Knowledge Management in Centralised Organizations
}

\author{
Péter KORONVÁRY, ${ }^{1}$ Péter SZEGEDI ${ }^{2}$
}

\begin{abstract}
The diversity of available technology challenges our organizations, leadership and (uniformed and civilian) co-workers day by day. Fiscal limits, conflicting technologies, constant need of unavailable knowledge and various other environmental factors may get centralized organizations with positional power in critical situations in our century. This article tries to bring to front some arguments why knowledge management should be considered as a key part of the necessary solution in avoiding new risks we shall face in the $21^{\text {st }}$ century.
\end{abstract}

Keywords: management, leadership, knowledge organization, technology, public administration, military

\section{A Cavalcade of Opportunities}

The world of "smart" tools can astonish anybody who grew up in an age when the regular way to interact with distant friends, acquaintances or relatives was writing a postcard. Even the coming of the telephone (and, do understand it well, we are talking about the wired dial phones grandpas still prefer to use as their fingers are too big to use a mobile) caused serious restructuring in the behavioural patterns as well as that of the living space or the social patterns. Once there will come some historian to write lengthily about how telephones conquered the streets and apartments, where they were stationed, how they were moved within the house or flat, and how they became from status symbols work instruments and, by now, artificial body parts of practically any human being under the sun, and how it became from a highly private act into an openly done one irrespective of place, time or audience.

The purchase of a mobile may be even more troubling. The cavalcade of makes, brands, versions, types, colours and, of course, prices can easily make the average over-aged adult dizzy. If you give a closer look, however, it may be that the various gadgets begin to group into sets. Classification makes orientation a lot easier.

In everyday situations classification is usually done according to the particulars of the potential buyer. Certain people consider design and colour, others also brand and technological specifications, while there are some who follow fashion or function, and most, of course, consider, in one way or another, the price.

There are the most modern high-tech power machines, the automatic super-smart pocket mobiles with more functions one can use in a lifetime and with comparable capacities to a good desktop computer, and in fact with a number of accessories they are capable of executing very similar functions too, and much more. Their most talkative

Assistant Professor of the National University of Public Service; e-mail: koronvary.peter@uni-nke.hu

Senior Officer of the Hungarian Defence Forces; e-mail: szegedi.peter@hm.gov.hu 
characteristics for the everyday man are that you need an evening course to learn how to use them and a lifetime to pay its price. And the running costs, if you want to make use of all the utilities at a professional level, they may be unacceptably high for the average wage earner. They are pretty, they are lean, they are the dream of tekkies and the status symbols (and sometimes probably also important multifunctional tools) of top managers. And yes, you can use them even as a telephone.

There are the middle-market bracket mobiles, with less fantastic prices and designs. The difference for the everyday user is mostly formal: their design makes use of more Spartan, more affordable materials, keeping as much as possible the elegance of lines and curves. Functionally they are capable of the same things, probably less efficiently and there may be reasonable differences in the quality of output too, but the everyday mobile buying individuals will see little of this. Evidently, they offer for them a much better value for price than top models, not to mention that they do not have to sell their children's future to pay them. Running costs are usually affordable for most living from a salary as telephone companies from time to time promote such medium-priced gadgets by offering them together with certain really advantageous packages. Their use meeting the full potentials of such a tool, however, may also require relatively more expense per month.

There are also various corresponding "no name” phones on the shelves produced by companies which either will make themselves a name in the future or sink soon into oblivion. They may be a bit heavier, a bit thicker, a bit less elegant in design, but they may also offer potentially interesting solutions due to their technical specifications, special service or better prices.

Also, you may see a number of "out-dated" mobiles on sale. They are relatively slow and have fewer or less worked out or older versions of functions, weaker hardware and software. They are beginning to become "problematic" as - due to the changes in fashion, software offerings and architecture-they are slowly becoming less and less compatible with the network, with the up-to-date software, with the upgrades of older software, they are the lower-market bracket products on sale for those who do not want to spend much and do not really need or want to use the exquisite online services.

Even some of the "mammoths" may turn up—-from the back shelves of deep, dark stores, second hand shops, they somehow may find their ways to the customer. They are the museum pieces, sometimes real archaic finds, with all the charms and beauty of antiquity-they are big, massive, thick and "stupid”, offering much fewer functions and weaker capacities as today's gadgets. Even so, they sometimes prove to be pretty functional, even surprisingly so. Not much time and children will find too difficult to use them-even their old users will need some time to find out how they actually can send messages on their old gadgets and be surprised how they could use them without any opportunity for reading or writing e-docs, watching films, or linking to the World Wide Web. They are the fountain-pens of the world of 3D information technology. Spare parts, accessories may already be difficult to find, their cooperation with the modern electronic tools is problematic. And even so, there is something interesting happening here...

There are copies of these "mammoths" present in masses in supermarket offerings. They look like mammoth, smell like mammoth, taste like mammoth. However, they are different. They are cheap, small, practical. They are able to offer the user a basic set of functions at a relatively really good level of efficiency and effectiveness. Not the fancy 
3D internet highway functions, but the basic ones you really need. They do not overtly multifunction, they are not "smarter" than the user. They offer clean functionality, polished, even sophisticated forms, practicality, but only within a limited range of possible tasks (phoning, messaging, calendar, register, notes etc.). Even if they look like old designs, they are practical and eye-catching. But they are different.

At first the similarity may confuse the inexperienced buyer but not for long. When you take such a gadget in your hands you will feel the difference. The materials are somehow different, better fit for mass production, perhaps, but also lighter, good-looking, easy to hold, good to touch. And they are-you will feel it when holding them-smaller. Even the tips of your fingers will perhaps be too big for them, you will have to use the edge of your nails. And the small screens have basic but comforting pastel colours, not the olden green background, black icons solution. Even the icons are different: easy to interpret, functional but pretty-tailored to the eyes of today's users. And the operations logic has also been made easier to understand. But the biggest anachronism: these gadgets are almost "empty": their mass-produced parts are so small that if the size of such phones would be reduced to the necessary, they would be simply too small to use. Even so, these components may be much more powerful than those of the original models-simply it is not worth to manufacture so weak and outdated parts any longer. With a bit of attention, they may last for ever but if they do not, it's no use to have them repaired. Costs would probably be much higher than the price of a new one. [10]

\section{Overburdening the People}

The example of mobile phones can be adapted to practically any equipment group used by our organizations, let them be office equipment, weapon systems or education technology. It shows us that the survivability of old systems may be better than one would at first dare to think. The barrier hardest to overcome may rather be on the human side-the knowledge incurred in their use and functioning may outdate faster than the technical solutions. As the proper maintenance and use of the newer and newer systems may require varying sets of skills and know-how, even changing sets of premises or concepts, organizations will sooner or later face a new problem in the field of the management of human resources development. Even today signs of over specialization may be observed. Operators and even technicians working with up-to-date technologies may not have that old set of skills and know-how necessary to integrate outdated but still functioning machines. The so-called interface problems between human and non-human elements in a process, as well as maintenance problems (e.g. unavailable or too expensive spare parts for older machines) are also recently faced by specialists. Organizational problems do peak, however, when even the necessary specialist knowledge will be of no avail. To get some hands-on experience of the problem, you can try to connect an about 10 years' old printer to a modern laptop and print a page or two. Do you have matching slot to the plug? If not, can you find a solution yourself? Have you got the right driver installed? If not, can you find it on the internet, download and install it? What if you do not find any solution to make the printer work together with your Win10? Can you change back to an earlier system? What about Linux? And if all this is not enough, what if it is an about 25-year-old matrix printer you have to integrate into 
your home computer network? In plain English, the real-time lengths of the equipment life cycles are rapidly becoming shorter and shorter.

Today's and tomorrow's operators, technicians and engineers are facing the problem of having to study more and more of the outdated machines in use, while trying to keep up with their rapidly developing profession. Seemingly by the middle of the $21^{\text {st }}$ century a major weakness of any piece of technology may be that it gets outdated much faster than the equipment itself would actually break. In addition, staff fluctuation may become faster than equipment life cycles, therefore old and new technologies may have to gain equal importance in education, training and development. Finally, new generations joining the organization will be socialized to the use of a quite different sets of technology than the previous ones or that the (more or less outdated) mixture used by the organization would require. These three problems will definitely add up to develop new risks of major management crises in our big organizations and systems, especially in the public sphere. Together with the culturally programmed tendency to think of organizational reforms in terms of structural changes instead of process development, the rethinking of human and non-human resource strategies at such highly technology-based, sizeable public organizations like the military ones seems to be unavoidable.

When taking a systemic perspective, a sincere overview of the organizational context seems to make it clear that the integration and comprehensive management of tasks, technologies and know-hows of public organizations, whether military or civilian, must be at regular intervals reviewed and adjusted. And these intervals are to be shorter and shorter in our century. It is of utmost importance that we find ways to permanently renew and improve our resources (both human and non-human) so that the execution of organizational tasks and the attainment of operative as well as strategic objectives remain possible. As long as the procurement of market leading technology for the whole of such big and complex organizations may be financially challenging, if not impossible, special effort is necessary to ensure the integration of old and new pieces of equipment in the very same system. Even if their parallel use makes the system more expensive to operate on the long run, the peculiarities of fiscal thinking and cash-flow may make it unavoidable. Not only the components and spare parts, accessories and complementary tools of ageing equipment may become sooner or later too expensive or even unattainable, but also those management, systems, operational etc. schemes, architectures, structures of concepts, thinking and techniques too in which they originally were meant to fit. Today's processes and problems are partially or wholly different from those they originally were able to handle. In many respects it may be that we are trying to make a 3D coloured cinema with a mid-20 ${ }^{\text {th }}$ century photographic camera with a 26-picture black-and-white film in it. Lots of time, energy and effort are wasted to solve the unsolvable and to bridge the technological gap between the realities in equipment and the level that would match $21^{\text {st }}$ century contexts and problems.

If creativity and a wide range of technological information is needed to match a whole bunch of ageing equipment with unfitting modern counterparts, education, especially the education of future operative and maintenance staff, including military technicians and engineers, has something to do there. If we have but paper and pencil to solve problems, our officers-to-be have to be taught how to do so. There is however no way to prepare well-functioning specialists by teaching what's new and up-to-date, and then sending them to work with stone-age equipment. Also, however, it is no solution to teach them the use 
P. KORONVÁRY, P. SZEGEDI: Thoughts on Technological Diversity and Knowledge Management...

of "existing” equipment as the gap between the know-how needed by presently purchased technology and the acquired knowledge would be too far away from each other. To train and pay two groups of technical staff is of course unimaginable. To teach old and new technology in their variety to the same set of people would require, of course, much more time and energy. Therefore, the only way out seems to teach a selection of both, using examples from the organization's practice, linked by what is today usually labelled as "creative problem solving”. [15]

It is therefore essential that new generations of our technicians and engineers are trained not only in using pen and paper, but also, they are educated in how to solve problems in such a technologically challenged environment. It is not enough for them to learn how current management information systems function and what they can be used for, or how to use a project management software, they should also acquire skills necessary to get to similar results with outdated technology, too. A Gantt chart may be calculated and drawn with pen and paper, if you know how to do it.

In an age when leaders have to be taught how to sign a document with a ceremonial fountain pen it is probably not much of a surprise if calligraphy, the skill of beautiful handwriting has found its way into the curriculum of certain universities. We have to do the same and teach skills that used to be basic a couple of decades ago but seem to be rare and necessary today. Even if students are taught, for example, how to use present documents and have to be able to fill in, following the standards and regulations, certain forms and tables, electronically or on paper, but this is not enough. They have to know what rules to follow when creating a new table. What are those rules of thumb that help them create one that can easily be interpreted by those who will be lucky enough to fill it? What to do if computer networks cease to function and our organizations have to get back to paper-based operations till the servers (or whatever) get repaired? What if the mobile systems cease to function? Or the satellites? Or all these together? What if all these will be part of a much bigger set of symptoms of a complex crisis following a natural catastrophe or terror attack? We need officers - leaders, managers, engineers or technicians — who know what to do under such circumstances, or at least they can find it out. Systemic thinking and creativity have to be integrated into $21^{\text {st }}$ century curricula in an age when everybody has Google, but most of them have no idea how to use it effectively. Seemingly, however, certain professional cultures do not support such ideas. [10]

The increasing speed of technical equipment dropping out of use will be a source of major crisis management problems in our age. To sustain basic operations and continue executing organizational functions without the technology we are so much used to is a task we are going to face on a regular basis. The present imprinted set of rules and regulations, manuals, accepted standards of behaviour etc. will hardly match an operational context "without gadgets" better than that of a technologically up-to-date one. In fact, we do not even need a crisis_-such interface problems may be more than enough to build one up and start is. As thirty years ago it was the use of British street phones or the place of postal codes on an envelope that may have caused headaches to tourists and post officers, today all individuals and organizations face a cavalcade of operation systems, linguistic and cultural complexities, the beauties of international English with its non-native varieties, differences in documentation and regulatory background of partner countries and/or organizations, just to mention a few of the non-technological symptoms adding to the developing crisis. [4] 
Whether we realize or we don't, we are living in a huge complexity of interface problems where proper, ethical and even — at the first sight at least-logical regulations might add to our problems instead of helping to solve them. Just think of product manuals in the packing telling the same thing in sometimes twenty-something languages printed in 2pt small—and therefore totally unreadable-characters. [10]

Today's technological systems require operating staffs to acquire knowledge and skill sets under the pressure of the urgent need of further improvement. To add further knowledge and skills required by the integration of multi-generational equipment to their burden of continuous development will mean additional education costs and higher fluctuation as such well-trained problem-solving engineers will definitely find better paid jobs with international companies than with our public organizations. Furthermore, their effectiveness will always be strictly limited by the outdated systems they will be requested to operate and maintain. [9] What's more, they will also be bound by their working environment at other levels too-let us think of, for example, the cultural and regulative framework the military and other public organizations exist within. [15]

The speed of technological development is seemingly continuously growing. Public budgets do not allow to introduce the newer and newer generations of modern tools and equipment. Some speak of virtual warfare and virtual client service at government offices, but it is only the gap between the technologically possible and the reality that is widening. We are at a point where the choice between financially feasible working solutions and the "big jump" to close up behind the top technological leaders has to be taken and according to the decision our governments and organizations have to define strategies for the rest of the century. The economic realities of Europe may rule out the high-cost alternatives in most areas of the public activities, but perhaps there is still enough reserve in the system to choose rapid development at least in some small segments. The later strategic decisions are taken, the fewer areas of development we can rationally expect to remain on the menu. [8]

The amortization of our present systems is in a phase when in some cases it is only the historic value of some technologies still in use that can be expressed with a positive number. Our multigenerational systems, however, will seemingly have to be staying in use as long as we can find or train personnel to maintain and operate them. [6] A major hindrance in this respect is the tendency of centralized organizations to neglect the proper management of organizational knowledge development. Without special managerial effort to fight this trend, as a result also organizational innovativeness, internal motivation building, professional and personal development, even organizational development will suffer. [14] Undeveloped, unmanaged knowledge will soon become outdated and irrelevant, useless. With the right management attitude, however, there is a chance that organizational leaders may keep up a situation where operative objectives may be reached; the question is, at what price. [9] There must be other solutions to develop our organizations in a (functionally, economically, socially etc.) more effective way. [10]

Our (higher education, public administration, national defence, law enforcement etc.) organizations typically depend upon the collection, organization, analysis and use of data, information and knowledge. They all take it for granted that a certain idealized system of organized knowledge does exist. Their operations follow codified and standardized processes based on inherited, historic values that are held universally true but are, in fact, 
P. KORONVÁRY, P. SZEGEDI: Thoughts on Technological Diversity and Knowledge Management...

in some respects rather worn out or even atavistic. Tradition, institutions, culture in such organizations are phrases that are often used for hiding partial inertia. [11] Over-centralization, the overt functioning of "survival-orientation" in such systems based on positional power and the required and expected respect of rank are all symptoms that more often than not go together with the exclusion of people at lower organization levels from knowledge and information, and the avoidance of the mere acceptance of the existence of individual know-how of subordinates. [10] As a matter of fact, the exclusive right of the superiors to the possession of knowledge (or even the belief in it!) is a powerful tool to the ideological strengthening of their positional standing. Not only is it against the interests of superiors to collect knowledge attainable within the system bottom-up and to make it available for others, but they also may take such suggestions as a personal attack against their own positions.[12] They will function as powerful filters within the organizational information system letting through exclusively those bits of information they find safe, relevant and important for their own purposes. [1]

\section{Special Leadership Effort Needed}

Any organization that manages to bottleneck in its own internal communication channels will become unable to identify movements in their environment. Neither those offering opportunities, nor those causing trouble. With extensive leadership effort, the creation, strengthening and regular development of those systems processes are capable of identifying, analysing and interpreting potential problems. To do so, organization leaders have to see to it that (1) the regular collection and restructuring of information does take place unhindered, (2) the collected information will be continuously analysed and assessed, processed and shared so that they meet professional standards, (3) the necessary resources (units, people, functions, tasks, place, equipment, authorizations, access etc.) are provided so that the processes involved may be run by knowledge management professionals. The creative use of present equipment may certainly reduce costs, for example the use of a Linux operation system and free office software may help to keep older desktops and laptops functioning. [15] [9]

The creation and development of adaptive and agile management of organizational knowledge in line with the organization's strategic objectives is an important part of the solution to the problems of centralized organizations. To set it up, we shall be in need of the support of all the analytic, critical, creative, intuitive, networking, project-management etc. skills available. The development of such skills with the help of available techniques and methodologies such as Total Systems Intervention, [7] de Bono’s thinking tools [3] or Action Learning [13] is doable, but the integration of such practices in the daily decision-making processes does need further leadership attention and effort. [15]

The target can be to intentionally prepare public organizations to identify and actively utilize the necessary knowledge(s) in and around to identify and prepare for various environmental effects under a strong leadership. Reforms and structural changes may strengthen the risks of losing professional competencies of the organization, both on the rational-analytic side (explicit knowledge) and on the intuitive one (tacit knowledge). To create an ideal system where the knowledge of the co-workers is permanently available 
for each other and the generation and utilization of new ideas are actively maintained by ongoing organization problem-solving processes is an objective they should pursue without cease. [9] Such an active organizational thinking may be able to identify changes in the organization's environments, mission and/or objectives, update organizational SWOT-s and analyse them, identify missing knowledge inputs and potential sources to acquire or develop them, and make sure that the necessary professional know-how as well as organizational knowledge reaches wherever they may be needed in time and in the form best fit for the potential users. [2] [15]

Such organizational knowledge may then be channelled also towards education. While higher education institutions may play a key role in identifying, analysing and introducing the necessary concepts, methodologies and tools in setting up working knowledge systems as well as in the dissemination and circulation of current theoretical and practical knowledge, hands-on experience and practical information from the actual problems arising in the course of their introduction and use may come only from the "battlefield". The education of new generations of young professionals must therefore take place in at least two very different environments that should work together, even intermingle, but never be mixed up and even confused: the university and the workplace. The common effect of the two very different types of experience will create in the learner the necessary "creative chaos", a mental state or space for conflicting inputs necessary to practice "thinking skills" needed so much in the problem-solving process. [12]

There is no learning simulation or seminar assignment that may prepare for the organizational realities. Professionals are made in practice. Education, however, can supply the necessary skills, capabilities and knowledge to see tasks, processes and structures from different aspects and perspectives. The aim is to mentor new and not-so-new generations of professionals to be able to trust and value such generational differences and share with each other what they are good at. [15] If indoctrination and socialization processes in our organizations work against this, and kill in the name of "tradition" all hope for transition, development and change, if we make use of financial and technological limitations as excuses for maintaining the past instead of moving toward the future, we are lost. It does not matter how up-to-date knowledge new colleagues bring to the organization if they are not allowed to use it. [9] Either they will be frustrated and leave the organization, or they will bend to the force of organizational culture and take over outdated patterns of thinking. In both cases, our organizations are bound to lose. It is not enough therefore to educate, train and mentor professionals-to-be, but there is also an urgent need to do the same at least with the core members of the organization. [2]

Centralized complex structures based on positional power-this is how most of our public organizations can be described. The textbook characterization of such systems will be a key element of coming organizational and social crises. Fiscal problems only add to the risks. We have, however, possible (partial) solutions at avail, such as knowledge management. In case we decide to adapt them, centralization and a strong, change-oriented leadership may even be advantageous in preparing for the coming wave of challenges. And then probably statistical proofs of their excellence will also improve. [5] 
P. KORONVÁRY, P. SZEGEDI: Thoughts on Technological Diversity and Knowledge Management...

\section{References}

[1] BELÉNYESI E.: Hatékony önkormányzati kommunikáció - a tudás megszerzésének lehetőségei. Pro Publico Bono: Állam- és Közigazgatástudományi Szemle, 1 (2011). www. propublicobono.hu/pdf/Belényesi\%20E.pdf (Downloaded: 01.10.2015)

[2] BENCSIK A.: A tudásmenedzsment elméletben és gyakorlatban. Budapest: Akadémiai Kiadó, 2015.

[3] de BONO, E.: Six Thinking Hats. Granica Editions. Boston: Little, Brown and Company, 1986. www.ilahas.com/sirpabs/ ebooks/Social\%20Interactions/Six\%20Thinking\%20 Hats \%20-\%20Edward\%20de\%20Bono.pdf (Downloaded: 20.07.2016)

[4] BUDAI B.: Az e-közigazgatás elmélete axiomatikus megközelítésben. Információs Társadalom, 9 (2009), 68-79. www.infonia.hu/ digitalis_folyoirt /2009_2/2009_2_budai_ balazs.pdf (Downloaded: 01.10.2015)

[5] BUKOVICS I.: A fenntartható ,jó állam” paradigmája. Polgári Szemle,10 3-6 (2015). www. polgariszemle.hu/?view=v_article\&ID=617 (Downloaded: 20.07.2016)

[6] CSEPELI GY.: A szervezkedő ember: a szervezeti élet szociálpszichológiája. Budapest: Osiris, 2001.

[7] FLOOD, R. L, JACKSON, M. C.: Creative Problem Solving: Total Systems Intervention. Hoboken: Wiley, 1991.

[8] HANDY, C. B.: Gods of Management. The Changing Work of Organizations. New York: Oxford University Press, 2016.

[9] Tudásmenedzsment a tanuló társadalomban, oktatás és készségek. OECD, 2001. www.oecdbook shop.org/get-it.php?REF=5LMQCR2JCGG1\& TYPE=browse (Downloaded: 06.08.2015)

[10] KORONVÁRY P., SZEGEDI P.: Tudásalkalmazás és tudásgondozás. Hadmérnök, X 4 (2015), 217-226. www.hadmernok.hu/154_20_koronvaryp_szp.pdf (Downloaded: 17.05.2016)

[11] KORONVÁRY P., SZEGEDI P.: Thoughts on Understanding Our Organizations. Hadmérnök, X 4 (2015), 227-236. www.hadmernok.hu/154_21_koronvaryp_szp.pdf (Downloaded: 17.05.2016)

[12] KORONVÁRY P., SZEGEDI P.: Repülőgép üzembentartó szervezetek humán erőforrásának tudásalapú fejlesztése. In. BÉKÉSI B., SZEGEDI P. (szerk.): Repülőműszaki üzembentartó szervezetek müködésével, fejlesztésével kapcsolatban. (Tanulmánykötet a BSc, MSc hallgatók számára) 49-63. Szeged, 2016. https://ludita.uni-nke.hu/ repozitorium/bitstream/handle/11410/10227/Tanulm\%C3\%A1ny-Repm\%C5\%B1szaki. pdf?sequence=1\&isAllowed=y (Downloaded: 17.05.2016)

[13] KRAMER, R: How Might Action Learning Be Used to Develop the Emotional Intelligence and Leadership Capacity of Public Administrators? Journal of Public Affairs Education, 13 2 (2017), 205-242. www.jstor.org/stable/pdf/40212728.pdf?seq=1\#page_ scan_tab_contents (Downloaded: 17.05.2016)

[14] SÁNDORI ZS.: Mi a tudásmenedzsment? Tacit és explicit tudás. http://mek.oszk. hu/03100/03145/ (Downloaded: 17.05.2015)

[15] TOMKA J.: A megosztott tudás hatalom. Budapest: Harmat Kiadó, 2009. 